\title{
Massive non-traumatic calcification of the medial collateral ligament of the knee
}

\author{
Themistoklis Vampertzis, ${ }^{1}$ Filon Agathangelidis, ${ }^{2}$ Erato Gkouliopoulou, ${ }^{2}$ \\ Stergios Papastergiou ${ }^{1}$
}

Orthopaedics Department, Agios Pavlos General Hospital of Thessaloniki, Thessaloniki, Greece

${ }^{2}$ General Hospital of Veria, Veria, Greece

\section{Correspondence to}

Filon Agathangelidis, fagath@gmail.com

Accepted 10 December 2016

\section{DESCRIPTION}

A woman aged 69 years presented with chronic medial knee pain for the past 12 months. Apart from type 2 diabetes mellitus and hypertension, there was no medical history of gout, trauma, endocrine or metabolic disorders. Plain radiographs showed a massive well-defined calcification at the medial side of the knee joint (figure 1). The calcification's upper margin was near the origin of the medial collateral ligament (MCL) and the lower edge was at the level of the medial tibial condyle. Further MRI revealed that the calcification was within the substance of the MCL (figure 2). Osteoarthritis with medial joint space narrowing, osteophytes and degenerative meniscus tear were also present; however, the patient focused her pain along the MCL and not at the femoral or tibial condyle or along the joint line. Full blood count, inflammation markers and calcium levels were within normal limits. The lesion was surgically

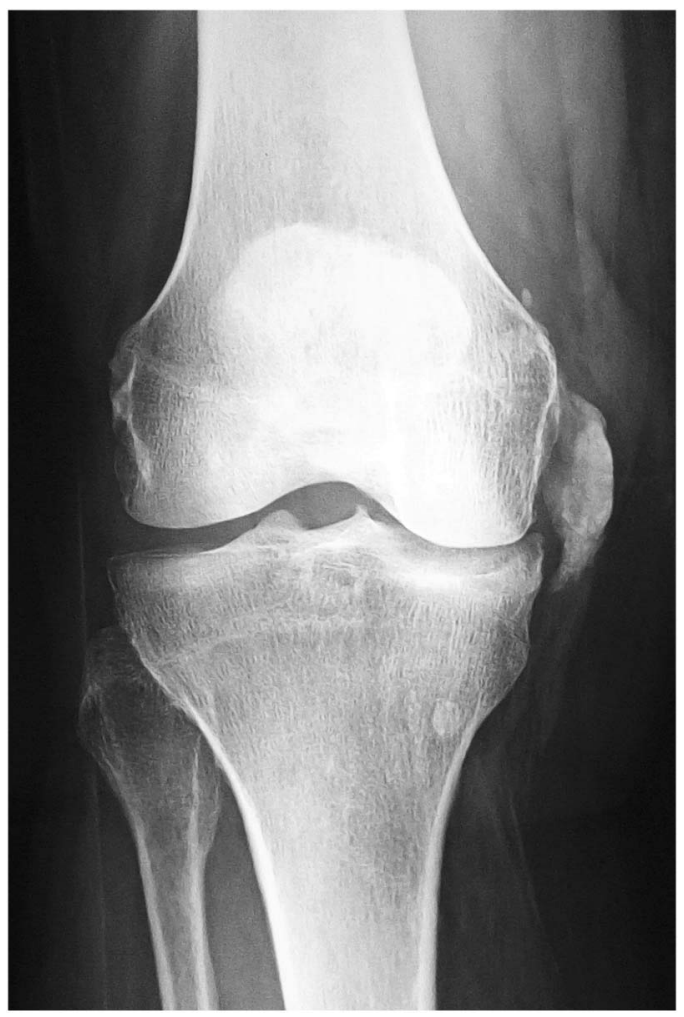

Figure 1 Anterolateral plain radiograph of the right knee showing a massive calcification extending from the origin of the medial collateral ligament to the level of the medial tibial condyle.

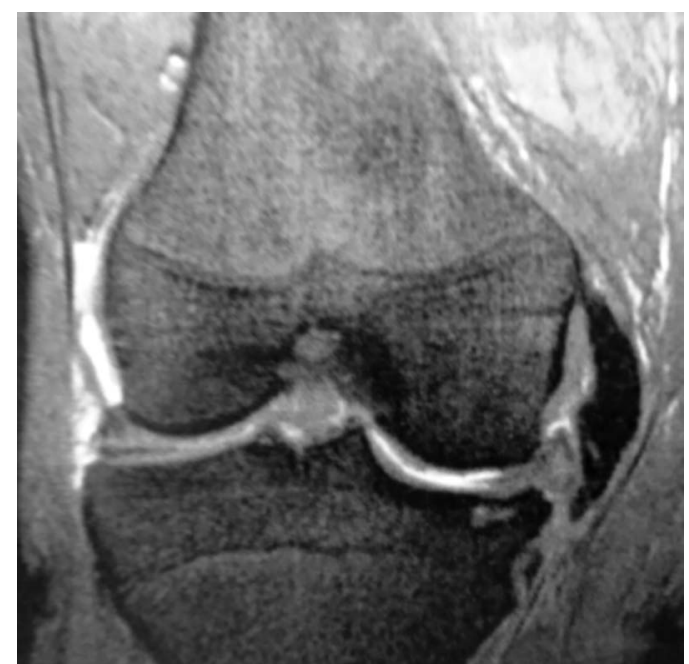

Figure 2 Fat-suppressed T2-weighted coronal MRI of the right knee shows the intraligamentous location of the lesion.

removed through a small incision over the MCL. Care was taken to protect the ligament's fibres and completely remove the toothpaste-like tophus. Histopathological evaluation showed nodular degeneration with calcium depositions. The patient was relieved from her symptoms immediately postoperatively and remained asymptomatic until the 2 years follow-up.

The differential diagnosis included Pellegrini-Stieda syndrome, but it was excluded since our patient had only calcification without the presence of ossified tissue. ${ }^{1}$ Treatment of a typical calcification or ossification of the MCL includes observation, infiltration with corticosteroids, shockwave therapy and surgical resection. Considering the large size of the lesion, surgical treatment was chosen which led to full resolution of the symptoms. ${ }^{2}$

\section{Learning points}

- Chronic pain located at the medial side of the knee is not always osteoarthritic pain. Thorough clinical and radiological investigation with plain radiographs and MRI in some cases is mandatory.

- Calcification or ossification of the medical collateral ligament of the knee responds well to conservative treatment. Surgical resection is needed in some cases with larger lesions. 
Contributors TV and FA wrote the manuscript and reviewed the literature. EG reviewed the manuscript and reviewed the literature. SP is the senior author and corrected the manuscript.

Competing interests None declared.

Patient consent Obtained.

Provenance and peer review Not commissioned; externally peer reviewed.

\section{REFERENCES}

1 Chang WC, Huang GS, Lee CH, et al. Calcification of medial collateral ligament of the knee: an uncommon cause of medial knee pain. J Clin Rheumatol 2006;12:204-5.

2 Muschol M, Muller I, Petersen W, et al. Symptomatic calcification of the medial collateral ligament of the knee joint: a report about five cases. Knee Surg Sports Traumatol Arthrosc 2005;13:598-602.

Copyright 2016 BMJ Publishing Group. All rights reserved. For permission to reuse any of this content visit http://group.bmj.com/group/rights-licensing/permissions.

BMJ Case Report Fellows may re-use this article for personal use and teaching without any further permission.

Become a Fellow of BMJ Case Reports today and you can:

- Submit as many cases as you like

- Enjoy fast sympathetic peer review and rapid publication of accepted articles

- Access all the published articles

- Re-use any of the published material for personal use and teaching without further permission

For information on Institutional Fellowships contact consortiasales@bmjgroup.com

Visit casereports.bmj.com for more articles like this and to become a Fellow 